\title{
The cult of amphioxus in German Darwinism; or, Our gelatinous ancestors in Naples' blue and balmy bay
}

\author{
Nick Hopwood
}

Received: 30 August 2014/ Accepted: 9 September 2014

(C) The Author(s) 2014. This article is published with open access at Springerlink.com

\begin{abstract}
Biologists having rediscovered amphioxus, also known as the lancelet or Branchiostoma, it is time to reassess its place in early Darwinist debates over vertebrate origins. While the advent of the ascidian-amphioxus theory and challenges from various competitors have been documented, this article offers a richer account of the public appeal of amphioxus as a primitive ancestor. The focus is on how the 'German Darwin' Ernst Haeckel persuaded general magazine and newspaper readers to revere this "flesh of our flesh and blood of our blood", and especially on Das neue Laienbrevier des Haeckelismus (The new lay breviary of Haeckelism) by Moritz Reymond with cartoons by Fritz Steub. From the late 1870s these successful little books of verse introduced the Neapolitan discoveries that made the animal's name and satirized Haeckel's rise as high priest of its cult. One song is reproduced and translated here, with a contemporary "imitation" by the Canadian palaeontologist Edward John Chapman, and extracts from others. Predating the American "It's a long way from amphioxus" by decades, these rhymes dramatize neglected 'species politics' of Darwinism and highlight the roles of humour in negotiating evolution.
\end{abstract}

Keywords Amphioxus - Edward John Chapman - Ernst Haeckel's Darwinism · Naples · Moritz Reymond · Humorous songs

From links in the great chain to model organisms, from the exotic to the domesticated, researchers have long placed special species on royal roads to knowledge. Evolutionists prize living fossils that might evidence the major transitions, such as the lancet-shaped sand-dweller of a few centimetres that in 1834 the Naples naturalist Oronzo Gabriele Costa recognized as a simple fish (De Ceglie

\footnotetext{
N. Hopwood $(\bowtie)$

Department of History and Philosophy of Science, University of Cambridge, Free School Lane,

Cambridge CB2 3RH, UK

e-mail: ndh12@cam.ac.uk
} 
1999, pp. 87-99; Fortey 2011). From the 1860s the 'German Darwin' Ernst Haeckel celebrated amphioxus, also known as the lancelet or Branchiostoma lanceolatum, as the primitive ancestor of all vertebrates because, though limbless and headless, it contains an axial rod or notochord. The Russian embryologist Alexander Kowalevsky's discovery, again in Naples, that it develops like the swimming larvae of the ascidians, or sea squirts, let Haeckel bridge the invertebrate-vertebrate divide (Beeson 1978; Mikhailov and Gilbert 2002; Fokin and Groeben 2008, pp. 99-102; Fokin 2012). Widely studied as the elementary vertebrate around 1900, amphioxus went out of fashion with the mid-twentieth-century decline of comparative anatomy and embryology. The renaissance of 'evolution and development' revived interest in what are now recognized as three genera containing some thirty species. Promoted by genome sequencing from nearly-vertebrate to basal chordate, the larger category of notochord-containing animals, the lancelet was "set to re-enter public life" (Gee 2008, p. 999; also Putnam et al. 2008; Bertrand and Escriva 2011). When the daily press reports as news that not just "[s]upermodels", but all backboned forms "owe their body shapes to a limbless, headless fish-like creature likened to an 'animated anchovy fillet',, it is high time to re-examine those first years of fame.

Disputes over vertebrate origins are notorious for the variety of putative ancestors that challenged amphioxus and ascidian since Anton Dohrn, Haeckel's estranged student and founder of the Naples Zoological Station, hypothesized changes in function that pointed to direct descent from annelid worms (Dohrn 1875; Kühn 1950; Ghiselin 1994; Maienschein 1994; Caianiello 2014; also Nyhart 1995, pp. 243-277). But survey histories have concentrated on specialists and, by chasing new ideas, have over-emphasized minority views (Gee 1996, pp. 84-159; Bowler 1996, pp. 141-202). We know that "[t]he theme of progress and degeneration ... permeated the debate" (Bowler 1996, p. 146), but little about even the most prominent ancestor's public life. To reveal how amphioxus caught the imagination when Haeckel persuaded general readers to revere that venerable beast as "flesh of our flesh and blood of our blood" (Haeckel 1874, p. 340), this article goes beyond his own works, monographs and journal articles to magazines, newspapers and, especially, books of songs and cartoons.

The soundtrack to the recent revival, "It's a long way from amphioxus", was written in the US in 1921 to the tune of the World War anthem "Tipperary", and expresses by then conventional affection. ${ }^{2}$ Four decades earlier, and coming out of a still older German tradition of science and song (Jackson 2003), rhymes by Moritz Reymond with sketches by the caricaturist Fritz Steub calmed a bitter confrontation over "Haeckelism". They celebrated the discoveries of what a free English

\footnotetext{
1 Roger Highfield, "Body-shapes are 'down to limbless, headless fish-like creature'”, Telegraph, 18 June 2008, http://www.telegraph.co.uk/science/science-news/3344789/Body-shapes-are-down-to-limbless-head less-fish-like-creature.html, last accessed 25 Sept. 2014.

2 “Songs about science VII: 'It's a long way from amphioxus"”, Nature News Blog, 19 June 2008, http://blogs. nature.com/news/2008/06/songs_about_science_vii_its_a.html; further: Maienschein (1994,pp. 465-466); Joe Felsenstein, "The amphioxus song, or, 'It's a long way from amphioxus", http://evolution.genetics. washington.edu/amphioxus/amphioxus.html, last accessed 9 Jan. 2014; and on evolution songs: Smocovitis (2009).
} 
translation called "our gelatinous ancestors" "in Naples' blue and balmy bay" (Agorastes 1878), and satirized Haeckel's rise as high priest of an amphioxus cult. They dramatize neglected 'species politics' of Darwinism and highlight the roles of humour in negotiating evolution. ${ }^{3}$

Illustrated songs about German scientists studying vertebrate origins in Naples are a fitting topic with which to honour Christiane Groeben, who has not only contributed much to our understanding of the Zoological Station and debates involving Dohrn. She has also kept alive his tradition of cultivating the arts in relation to the fauna and flora of the gulf (e.g., Groeben and Gambi 1992; Groeben 1995), including in memorable musical performances at the Ischia Summer Schools.

\section{Flesh of our flesh}

In 1834 Costa, a professor of zoology embarking on a big study of the rich fauna of the Kingdom of Naples, reclassified what, from a preserved Cornish specimen, the German zoologist Peter Simon Pallas had 60 years before described and depicted as a mollusc. Costa placed live animals from Posillipo, just north of the city, as relatives of cyclostomes, the jawless hagfish and lampreys, though dissection soon showed that amphioxus deviated more from these than they did from salamanders (Willey 1894, pp. 7-9). Costa's interest in links between classes and Europe-wide discussion as an intermediate form (De Ceglie 1999, pp. 87-99) confirmed amphioxus as the most primitive vertebrate (Gegenbaur 1859, pp. 386-393). In the 1860s the Jena zoologist Ernst Haeckel, with his anatomist colleague Carl Gegenbaur, evolutionized the science of form (Nyhart 1995; Richards 2008; Hopwood 2015, pp. 61-88) and gave it an even bigger part.

Haeckel filled the first Darwinist system, his Generelle Morphologie (General morphology), with cosmic ambition, new technical terms, ferocious polemic, bold pedigrees all the way up to human beings and taxonomic revisions which promoted amphioxus to a new subphylum, the Acrania or skull-less ones. As the single survivor of the first vertebrate division, Haeckel pronounced it "probably the last Mohican" of a once "richly developed and many-branched tree" (Haeckel 1866, II, p. cxix). The reference to James Fenimore Cooper's novel invoked imperialist elegies for the last representatives of lineages, tribes and species (Stafford 1994, pp. 232-260; Brantlinger 2003), but Haeckel in fact picked winners, stressing the nobility of amphioxus as an ancestor of the dominant line and the respect owed to age. The transition from the invertebrates to amphioxus remained mysterious, however; he adopted a marine roundworm as a hypothetical link, but there was as yet no convincing bridge.

From 1868 Haeckel's Natürliche Schöpfungsgeschichte (Natural history of creation) preached this Darwinist gospel and, over several decades, a dozen German editions and as many translations took it to the general educated public. Lacking fossils, his conjectural pedigrees relied on embryos, via the theory that individual

\footnotetext{
${ }^{3}$ For example, Browne (2001), Neyer (2009); for species politics: Hopwood (2011). The present article builds on the discussion, with respect not to amphioxus but to Haeckel's embryos, in Hopwood (2015).
} 
development (ontogeny) recapitulates that of the species (phylogeny). Still cautious about vertebrate origins in 1866, Haeckel now used Kowalevsky's work to argue that an invertebrate like an ascidian larva, itself derived from annelids, had developed in two directions: degenerating into the adult tunicates sitting on the sea floor and progressing to amphioxus and other vertebrates (Haeckel 1868a, pp. 409, 433-440). This story raised the credibility of the lancelet too. "We must thus contemplate amphioxus with special reverence", a "popular scientific lecture" proclaimed, "as that venerable animal which of all still living animals is alone in a position to give us an approximate idea of our oldest Silurian ancestors with backbones" (Haeckel 1868b, p. 42). Fine schematic plates of ascidians and amphioxus graced the second edition of the Schöpfungsgeschichte, bridging a "deep gulf" and allowing Haeckel to trace humans back to worms (Fig. 1). He told "speculative philosophers" to stop "building futile castles in the air" and think about these facts instead (Haeckel 1870, p. 673). Darwin's Descent of Man less polemically promoted the ascidian-amphioxus theory the following year (Darwin 1871, I, pp. 204-206). Humble origins were an old idea-liberals cared only how far a person had come and could go-but the specificity and degree of consensus were new.

Haeckel's pedigrees stirred up trouble from the start, but editors, journalists and general readers entrenched the Schöpfungsgeschichte in the optimistic, nationalist, anticlerical 'culture of progress' of the new German Empire and took these ancestors into middle-class homes. ${ }^{4}$ Then, in 1874, Haeckel came out with the Anthropogenie (translated as The Evolution of Man), a major statement of the relations between ontogeny and phylogeny and a salvo in the Kulturkampf, Chancellor Bismarck's anti-Catholic campaign (Haeckel 1874, pp. xi-xvi). Joining the nationalist monument-building (Belgum 1998, pp. 84-102; Jefferies 2003, pp. 59-72), the book proudly traced humanity back to amoeba, amphioxus, axolotl, Australian lungfish and ape (Hopwood 2015, pp. 108-119). Haeckel told readers that "ignorant theologians" and "anthropocentric" philosophers objected that his attitude towards amphioxus had "ridden roughshod over ... the dignity of humanity and most grievously insulted the divine human sense of reason". But, he insisted, the "thousand-year-old oak wood" it seemed natural to respect was as nothing compared to this little fish. If amphioxus lacked "skull, brain and limbs", this "flesh of our flesh and blood of our blood" still deserved more admiration and reverence "than all the useless rabble of so-called saints to whom our 'highly civilized' nations build temples and dedicate processions" (Haeckel 1874, pp. 337, 340). Haeckel deployed fresh empirical research and his own new argument that all true animals descended from a swimming stomach, or gastraea, to strengthen and expand his coverage of the ascidian-amphioxus theory (Beeson 1978, pp. 335-356). He mobilized these animals as secular icons and in a struggle for embryology

\footnotetext{
${ }^{4}$ For example, "Neue Literatur über Darwins Lehre von der Umbildung (Transmutation) der Arten", Ausland, 41 (1868), 673-682, on 681-682; "Ernst Haeckels natürliche Schöpfungsgeschichte. 2. Die Stammbäume für Thiere und Pflanzen", Ausland, 43 (1870), 710-715, on 712-713; "Darwin über die Abstammung des Menschen. III (Schluß)", Allgemeine Zeitung, Nr. 125B (5. Mai 1871), 2214-2215; on Darwinism in the periodical press: Kelly (1981), Daum (1998, pp. 300-323), Hopwood (2015, pp. 99-105); for the context: Blackbourn (1997, pp. 270-283).
} 


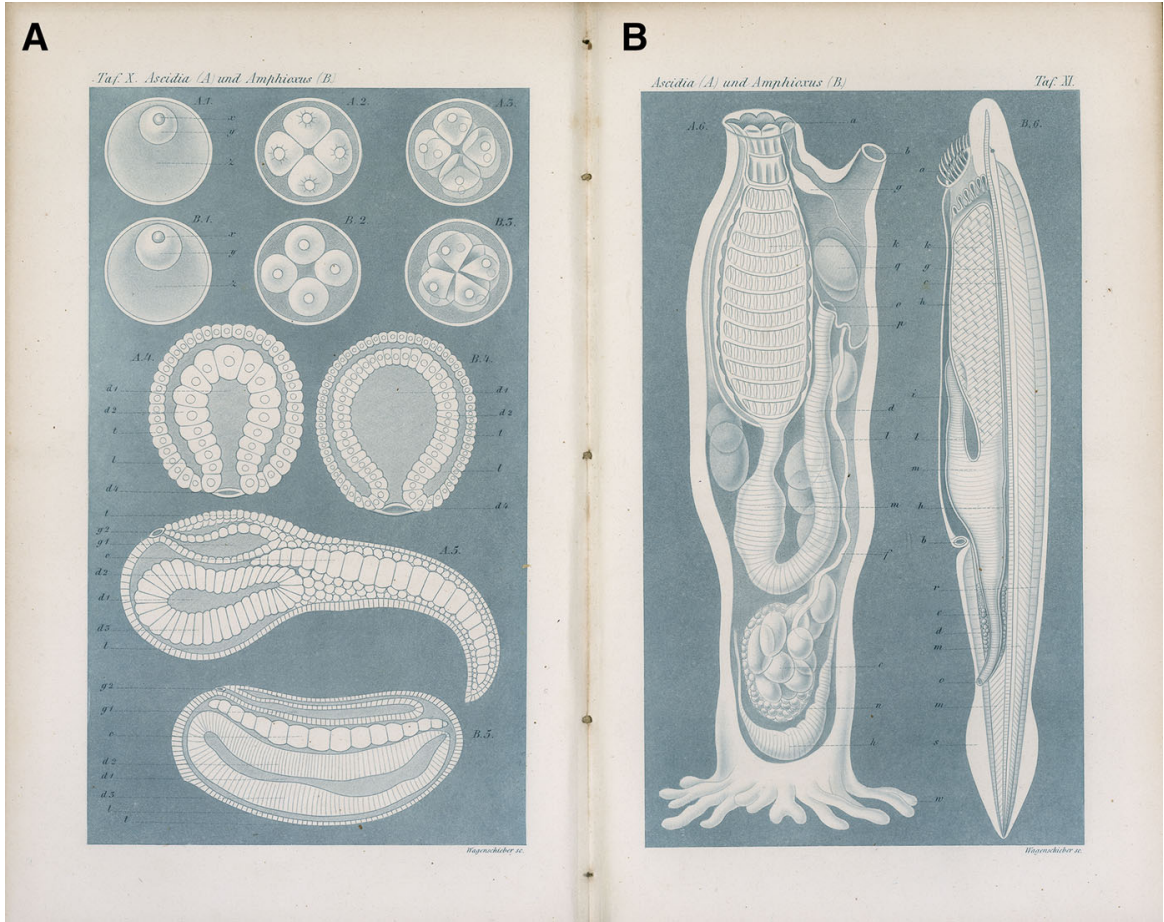

Fig. 1 Plates of the embryology and anatomy of ascidian (A) and amphioxus (B) in the second edition of Haeckel's Natürliche Schöpfungsgeschichte to show the "blood relationship of vertebrates and invertebrates". Simplified after Kowalevsky, plate $X$ represents the ontogeny in five stages from eggs to larvae, and plate XI the adults with the internal organization visible through the transparent skin. Copper engravings with blue wash by Wilhelm Wagenschieber from Haeckel (1870, plates X-XI). $21 \times 26 \mathrm{~cm}$

between phylogeny and physiology that politicized species choice (Hopwood 2011, p. 5). One look at amphioxus development, he declared, and the chick-based theory of his rival, Wilhelm His, "collapses like a house of cards" (Haeckel 1874, p. 629; also 1875 , p. 23).

More specialized than the Schöpfungsgeschichte, and hard for those Haeckel disparaged as "so-called educated" graduates of the classical grammar schools (Haeckel 1874, p. xi), the Anthropogenie disappointed high expectations of a good read, but many learned the arguments at second hand (Hopwood 2015, pp. 127-134). The liberal publicity machine announced the book with a review in the Illustrirte Zeitung (Illustrated news) that told progressives to study comparative embryology. Large wood engravings presented amphioxus and ascidians as "primordial ancestors of the tribe of backboned animals" (Fig. 2). "Die Gartenlaube (The bower), the family magazine with the huge run of nearly 400,000, also stressed their significance as a bridge. Without the "little lancet fish" we would

\footnotetext{
5 Zacharias (1875a); see also, e.g., "Häckel's Entwickelungsgeschichte des Menschen. III", WeserZeitung, Nr. 9995 (19. Nov. 1874, Morgenausgabe), 1-2; Zacharias (1875b).
} 
68

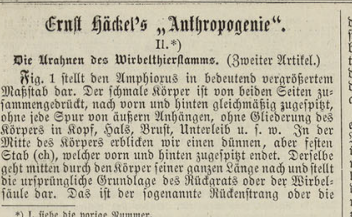

9Itustrirte ơciturg.

[N 1647. 23. Jautar 1875 .

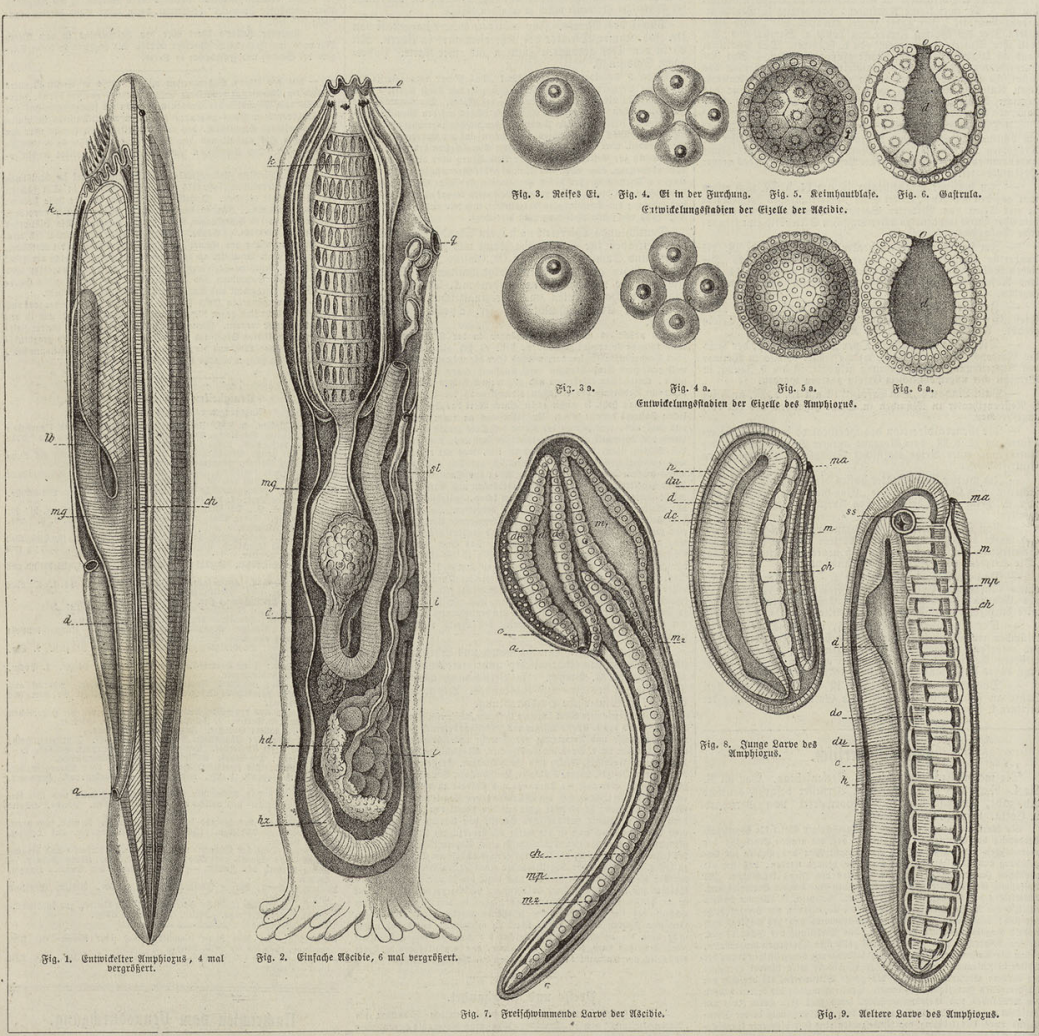

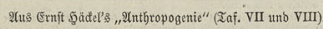

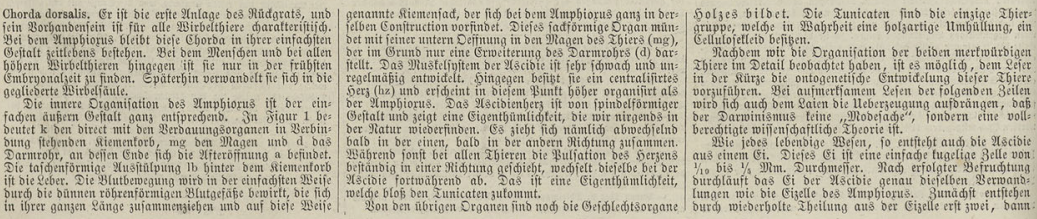

Fig. 2 Amphioxus and ascidian in the Illustrirte Zeitung. These wood engravings in Otto Zacharias's review of Haeckel's Anthropogenie are cruder than the original plates but reached more people. The magazine omitted cross-sections and a lamprey larva that Haeckel had added to present his more developed theory in the more specialized book. Zacharias (1875a, p. 68). $41 \times 29 \mathrm{~cm}$. Niedersächsische Staats- und Universitätsbibliothek Göttingen 
barely know we came from worms, a "kinship certainly more congenial to the Christian feeling of humility than descent from the apes". 6 But the Anthropogenie did not just give journalists material; it also goaded experts into warning the public (Hopwood 2015, pp. 119-126, 132-134).

Haeckel basked in adulation, but his polarizing rhetoric also provoked howls of opposition from scientists as well as philosophers and theologians. A disciplinary enemy, the physiologist Emil du Bois-Reymond, had already attacked his overstepping of the bounds of natural knowledge (Bayertz et al. 2007). Even fellow zoologists, most of whom by now accepted the fact of evolution, worried about the dogmatic presentation of personal speculations, exaggeration of his own novelty and intolerance towards other researchers' views. Few Darwinists endorsed every detail of his pedigrees and many objected to his gastraea theory (Nyhart 1995, pp. 168-206). Yet amphioxus had until now largely escaped specialist challenge.

Haeckel's advocacy and Darwin's endorsement had established the lancelet as the primordial vertebrate and built momentum behind the more controversial ascidian theory, but from 1875 other Darwinist theories began to compete (Beeson 1978). ${ }^{7}$ From Naples, Anton Dohrn urged followers of Haeckel and Gegenbaur to pay living conditions more attention. Then they would see that ascidians and amphioxus merely continued the degeneration that the parasitic cyclostomes had begun. Reduced to filtering food from sandy water, amphioxus represented "a degenerate fish", and the ascidians had declined even more (Dohrn 1875, p. 55; Ghiselin 1994, p. 63). For the Würzburg zoologist and authority on sea cucumbers Carl Semper, the other main advocate of the annelid theory, amphioxus was also no vertebrate (Semper 1875, p. 66; 1876a). This comment in Semper's institute journal gained currency when the veteran materialist and early Darwinist Carl Vogt deployed it in the liberal Frankfurter Zeitung to dismiss Haeckel's "mythical" pedigrees, and anti-Darwinists picked it up. ${ }^{8}$ Few were in any position to adjudicate, but expert disagreement made the choices look arbitrary and helped those who rejected pedigrees out of hand.

Haeckel defended himself, in a small section of a long polemic, by pretending that for consistency Dohrn would have to make the whole animal kingdom degenerate from the "sinless" Adam until the "unfortunate amphioxus, which had burdened itself with the most serious guilt, finally lost even its head" (Haeckel 1875, pp. 31-33, 88-89). But as religious and political protests rained down on

\footnotetext{
${ }^{6}$ Sterne (1875, p. 268); see also Bock (1875), and on the magazine, Belgum (1998). The journalist Ernst Krause (pseudonym Carus Sterne) tried to enlist Haeckel's help with drawing - hard for a periodical that preferred natural-looking scenes to the didactic, textbook-like cuts in the Illustrirte Zeitung: "It would be most suitable for these purposes if, in a section, e.g., of the Naples aquarium we could unite into a group picture an ascidian rooted on the floor a[nd] in the water amphioxus a[nd] sea lamprey with the larvae of all three species of animals" (Krause to Haeckel, 19 Nov. 1875, Ernst-Haeckel-Haus, Jena). The article appeared without illustrations.

7 They thus added to criticism by the aged Karl Ernst von Baer, reported in Huber (1874).

${ }^{8}$ Vogt (1875); "Ultradarwinismus und Dilettantismus. Aus der Laienperspective", Allgemeine Zeitung, Nr. 105B (15. Apr. 1875), 1625-1626. Semper would object to Haeckel's claim that he "had denied any relationship of amphioxus with the vertebrates" (Semper 1877, p. 35); Ernst Krause would regret that "poor amphioxus must share [Semper's] hatred of you" (Krause to Haeckel, 30 Jan. 1877, Ernst-HaeckelHaus, Jena).
} 
Haeckel, and the press amplified colleagues' censure of everything from pictures of embryos to speculations about cellular souls, objections to amphioxus as ancestor were still easily overlooked. For spokesmen of science the bigger issue was the threat from his behaviour to their freedom in the new state. In early 1876 Semper publicly targeted Haeckelism for falling into the same credulous dogmatism that its author repudiated in the churches, and so risking the status that Darwinism had brought zoology, but he mentioned amphioxus only in a note (Semper 1876b, p. 35).

Haeckel's reputation would never recover fully from these battles, but most competent researchers still credited him for pushing the theory of evolution through. As tempers frayed, humour, which had so far figured mostly in sarcasm between Haeckel and his critics, appeared as mediator. Rhymes went some way towards defusing a tense situation by separating Haeckel's excesses from commitments on which evolutionists just might agree.

\section{Haeckelism in rhymes}

Nature researchers in the German lands had long sung together to foster (male) camaraderie and cultural nationalism, validate specialized knowledge (Jackson 2003), and share the fun in songs such as Joseph Victor Scheffel's mock-tragic lament by the last ichthyosaur. A commission from the Bern scientific society spurred the newspaper editor Moritz Reymond to write humorous verses on intellectual fashions such as the Kulturkampf and medical advice, and Haeckelism became his greatest theme. ${ }^{9}$ With a title referring to Catholic books of daily prayers and the like for non-priests, and a focus on the Old Testament, Das neue Laienbrevier des Haeckelismus (The new lay breviary of Haeckelism) eventually ran to five books with cartoons by Fritz Steub of the Fliegende Blätter, the Bavarian Punch.

Reymond prepared Genesis, oder die Entwickelung des Menschengeschlechts (Genesis, or the development of the human race) for Christmas 1876. Shrinking the octavo lectures of the Anthropogenie chapter by chapter to a sexto-decimo of songs painlessly acquainted readers with the positive and negative sides of the original. Engaging with its reception too, the satire played on the symmetry between Haeckel's charges of ignorance and the exclusivity of his own neologisms, on the one hand, and the irony of his condemning church dogma while setting himself up as the "apostle of a new faith", on the other (Reymond 1877, p. 8). Reymond tackled the pedigrees at length, but left the hypothesis of amphioxus as ancestor unchallenged; the consensus was too strong and dissent not yet prominent enough. Two songs reviewed the discoveries that had revealed respectively the structure of amphioxus and ascidians and their embryology and thematized the German tradition of finding origins in and around the Mediterranean.

The first, to a folk tune previously used for a student song about Diogenes the Cynic and Alexander the Great, corresponded to Chapter 13 of the Anthropogenie

\footnotetext{
9 Deutsches Biographisches Archiv, s.v. "Reymond, Moritz"; Hopwood (2015, pp. 138-143). Reymond (1880b) discussed, in part sympathetically, the antisemitism of Wilhelm Marr.
} 


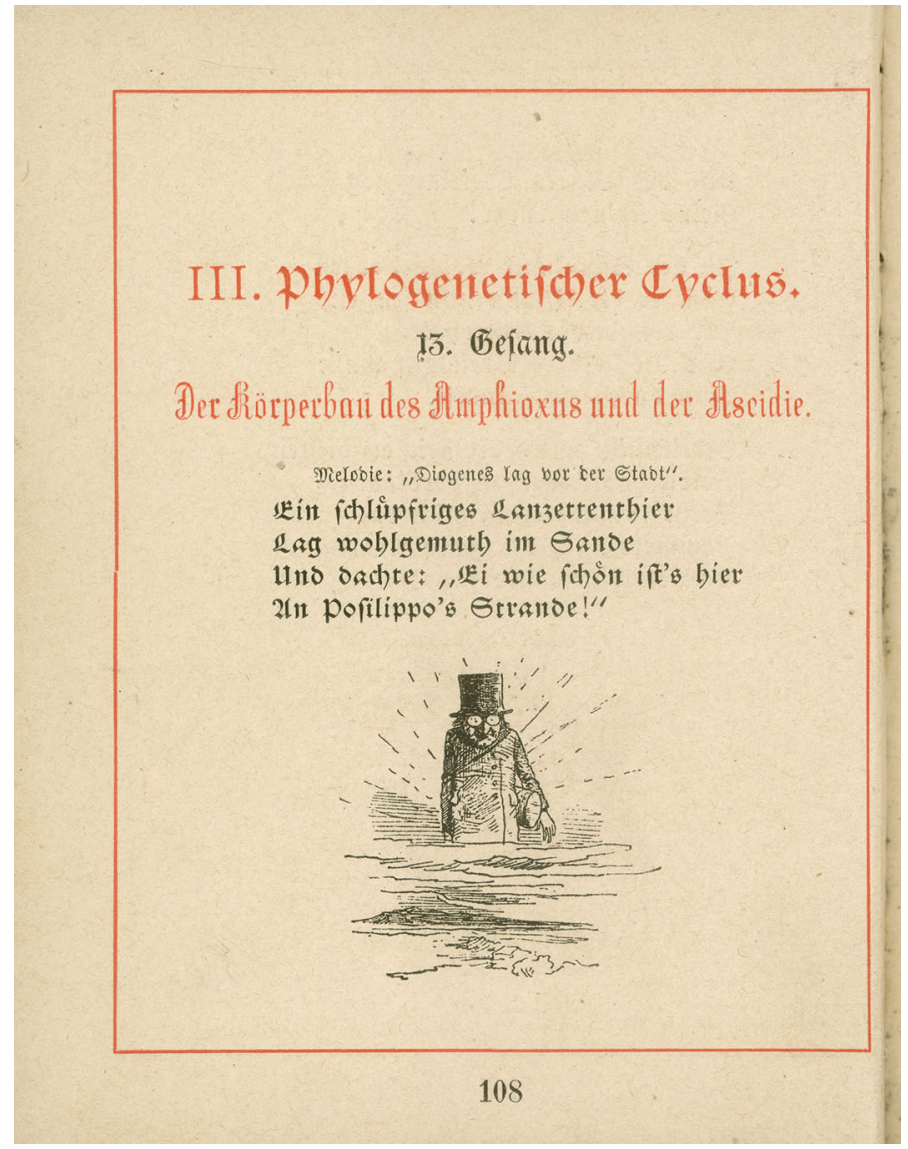

Fig. 3 A "grim zoologist" (Costa) "on the horizon". The illustration by Fritz Steub, like the one in Fig. 4, was added in the second and kept in this third edition. Reymond (1878, p. 108). Border $10.5 \times 8.2 \mathrm{~cm}$

and tells how zoologists' lancets raised the status of the lancelet (Reymond 1877, pp. 76-79). A series of encounters with Costa, Kowalevsky and Haeckel, the extent of whose hands-on research is exaggerated, prove fatal for the individual animals. Invoking Pallas fails to stop Costa testing his hunch (Fig. 3). But the species gain fame. Here is the complete song, "Der Körperbau des Amphioxus und der Ascidie" (The structure of amphioxus and ascidian), with my translation but without the four endnotes that explained the history in quotations from the Anthropogenie.

Ein schlüpfriges Lanzettenthier

Lag wohlgemuth im Sande

Und dachte: "Ei wie schön ist's hier An Posilippo's ${ }^{10}$ Strande!"
A lancet fish so slippery

Lay cheerfully in the sand

And thought, "Oh, isn't it lovely

Here on Posillipo's strand!"

\footnotetext{
${ }_{10}$ This was Haeckel's spelling, and hence Reymond's and Edward Chapman's below.
} 
Da stieg ein grimmer Zoolog

Empor am Horizonte,

Der Alles zu zergliedern pflog,

Was er erwischen konnte.

Er sieht das Thier und hebt es auf, Obwol es schneckenglatt ist, Und sagt: "Ich nehme Gift darauf, Wenn das kein Vertebrat ist!"

Das Thierchen seufzt: “Ach, geh'n Sie weg!

Das könnt' ein Jeder sagen!

Ich bin ja nur ein nackter Schneck-

Sie können Pallas fragen!"

Der Zoologe aber sprach

Zum großen Schreck des Findlings:

"Der weise Mann sieht selber nach

Und glaubt nicht Andern blindlings!"

Drauf schob die Pseudoschnecke er

Gefühllos in die Tasche,

Zerschnitt und setzt' sie hinterher

In eine Weingeistflasche.

Dies kam, wie sehr auch paradox

Es scheint, dem Thier zu Statten;

Denn seither zählt der Amphiox

Zur Crême der Vertebraten.

Und wieder schwamm im Mittelmeer

Ein Zoolog spazieren,

Wo die Ascidien stationär

Am Grunde vegetiren.

Mit einem Schleppnetz und Bedacht

Hat er an jenem Orte

So manches Stück zu Tag gebracht

Von dieser Würmersorte.
But then a zoologist grim

Rose up on the horizon,

Who used to dissect with much vim, Whatever he laid hands on.

He sees and snatches the creature Though smooth as a snail it be, And says: "My own life I'd wager, But vertebrate that must be!"

The animal sighs: "Be off, you!

Anybody could say that!

A slug is all I am, it's true-

Just go and ask Pallas that!"

The zoologist however spake

To great terror in his find:

"The wise man must his own look take

And doesn't trust others blind!"

With that the pseudo-snail he tucked Callously in his pocket,

Cut it to bits and these then dunked

In a bottle of spirit.

However great a paradox

This seems, the beast uprated;

For since that day ranks amphiox

As crême of the vertebrated.

Again a zoological

Went for a swim in the Med,

Where ascidians statical

Vegetate on the seabed.

With drag-net, care and attention

$\mathrm{He}$ in that same place did bring

To light a splendid selection

Of this type of wormy thing. 
Es barg der Cellulose-Schlauch

Die wunderlichen Alten

Und gleich die lieben Kleinen auch In der Cloake Falten.

Sie kamen unter's Mikroskop, Sie kamen unter's Messer; Sie starben sich zu Tod' darobDoch Häckeln ging es besser!

Denn sieh! Ein Wunder hatte da Enthüllt mit einem Mal sich:

Die Larve der Ascidia

Erwies als vertebral sich!

Der Häckel hört's von ungefähr Und schnürte gleich den Ranzen Und ging an's Mittelländ'sche Meer Drei Monat in Vakanzen.

Es forscht' der große Zoolog Von früh bis Abends spät hier Und fand, wie sehr doch analog Ascidie und Lanzett-Thier.

Was ihm gemangelt bis anhin In seiner Ahnenreihe, Das Bindeglied nach unten hinDas waren diese zweie!

Nun war die Lücke ausgefüllt, Die Reihe schön geschlossen, Und das Geheimniß uns enthüllt, Wie wir dem Wurm entsprossen!

Ascidie und Amphiox, Ein Glas zu Eurem Ruhme! Den Wurzeln unsers Ahnenstocks Bring Jeder seine "Blume"!
The cellulose tunic it held The wondrous adults mature And the dear babies also dwelled In cloacal folds secure.

They came under the microscope, They came under the cutter; They died a death without a hopeBut Haeckel's life went better!

For see! A miracle had there Revealed itself once for all: The larva of ascidia Turned out to be vertebral!

Haeckel heard, by chance 'twas really, And packed his bags right away And went down to the Middle Sea For three months of holiday.

That zoologist searched the ground From early till evening late And most analogous he found Ascidian and lance-let.

What till then he had been lacking In his ancestral series, The downwards link a-connectingThat was this pair of beasties!

Now the gap it was nicely healed, The series well closed henceforth, And the secret to us revealed, How from the worm we sprang forth!

Ascidian and amphiox, Let's raise a glass to your fame! The stem of our ancestral stocks Let everyone toast your name! 
Listeners were invited to drink to their newest-oldest ancestors.

The next chapter, and so the next song, was about the embryology-presented through a chance meeting over a beer between Kowalevsky and "Brother Straubinger", a travelling journeyman whose literary career had begun in the drinking song of a Bavarian medical student some 50 years before (Reymond 1877, pp. 79-83). There is space here only for a selection of verses in which Straubinger recounts what happened after the St. Petersburg professor invited him out. Kowalevsky, whose report described amphioxus as starting to mate on warm May evenings between seven and eight, asks his acquaintance to appear on the beach "behind Vesuvius", "sober" and at half past seven precisely (Fig. 4).

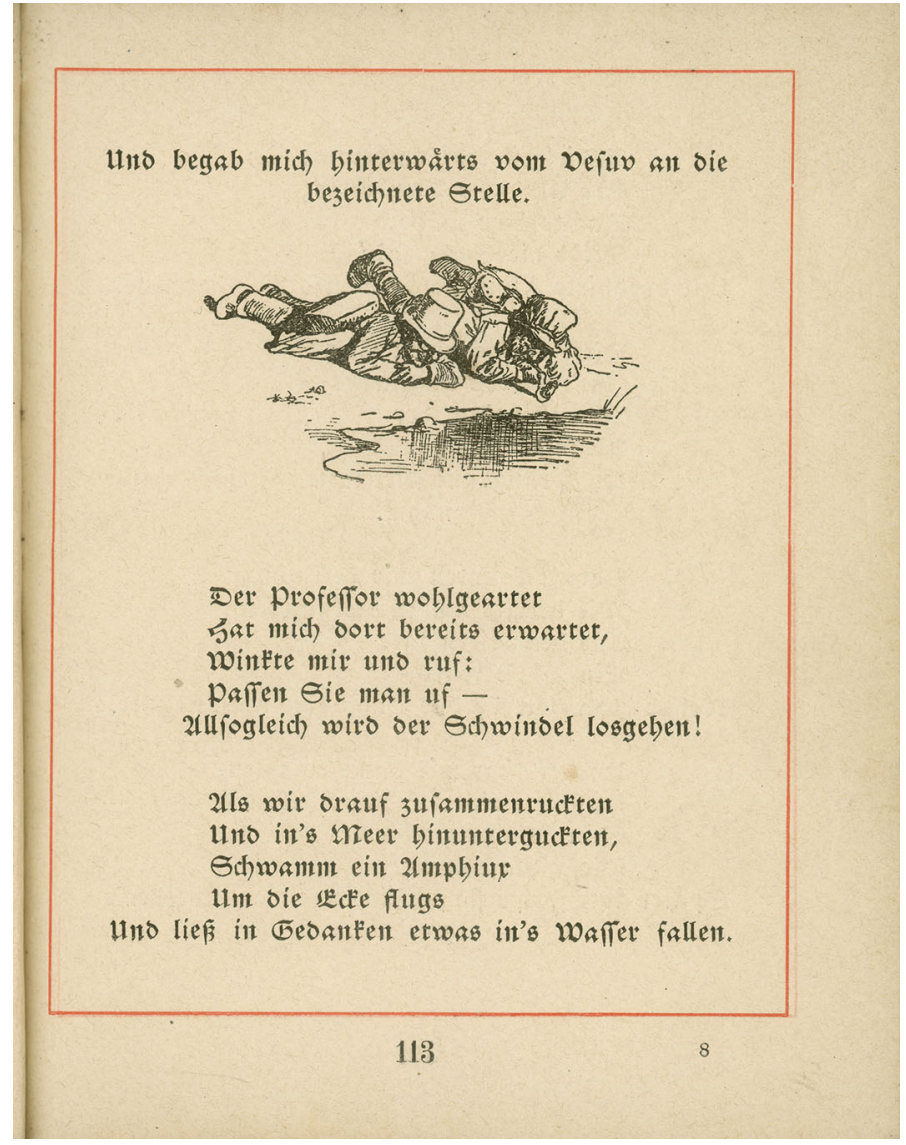

Fig. 4 Alexander Kowalevsky and Brother Straubinger watching amphioxus mating in Naples. By Fritz Steub, from Reymond (1878, p. 113) 
Der Professor wohlgeartet

Hat mich dort bereits erwartet,

Winkte mir und ruf:

Passen Sie man uf-

Allsogleich wird der Schwindel losgehen!

Als wir drauf zusammenruckten Und in's Meer hinunterguckten,

Schwamm ein Amphiux

Um die Ecke flug's

Und ließ in Gedanken etwas in's Wasser fallen.

Alldieweil traf unterwegs ihn

Die Madame Amphiöxin;

Dachte sich: "Oho,

Steht die Sache so?"

Und deponirte selbigenorts diverse Amphioxeneier.

Diese amphioxigen Eier

Int'ressirten ungeheuer

Kowalewsken, der

Alsbald hinterher

In's Meer sprang und dieselben

mit nach Hause nahm.
The professor, good-humouredly,

Was there and waiting already,

Waved and gave a shout:

Hallo, mate, look out-

The show is going to start any minute now!

When we moved closer, he and me,

And looked down, down into the sea,

An amph'ux swimmer

Sped round the corner

And, in thought immersed, let something fall into the water.

Where'pon an amph'oxy lady

Meeting him en route, silently

Thought to 'self: "Wahey,

Are things now that way?"

And deposited various amphioxus eggs in the very same place.

These eggs so amphioxical

Appeared of interest colossal

To Kowalevsky,

Who now directly

Jumped into the sea and took the same home with him.

Straubinger goes back to the Russian's lodgings and they watch the amphioxus develop.

Dorten konnten wir betrachten,

Wie bereits um Mitternachten

Aus den Eiern zart

Eine Blase ward,

Welche Kowalewsky das

Blastodermichen nannte.
There we could contemplate steady How around midnight already

Those eggs so tender

Became a bladder

Which Kowalevsky called

the blastodermlet.

The uneducated artisan, who symbolized conflict with the academic world, has difficulty with "the damned Latin names". Reymond thus both followed Haeckel and his readers in thematizing the difficulty of the esoteric science, and borrowed Straubinger's idiom to communicate some embryology: 
Doch im weiteren Entwickeln

Spürt die Larve nun ein Prickeln,

Rücken auf und $a b$,

Und ein Axenstab

Wächst ihr bratspießartig mitten durch's Gedärm.
Yet as it develops quickly

The larva now feels all tingly

Up and down its bod'

And an axis rod

Grows right through its intestines like a skewer.

Working up an appetite, Straubinger would not have minded hearing more over some spare ribs, "because you don't never know what education will be good for", but Kowalevsky sends him away hungry.

Admirers and critics of Haeckel liked the rhymes (Hopwood 2015, pp. 142-143). A Catholic reviewer was pleased to see Darwinism's true colors exposed, and for an editor of the leading anti-Darwinist science magazine "this food for the mind" complemented the Christmas sweetness as perfectly as "herring salad with Spanish pepper ... a stomach upset by marzipan". ${ }^{11}$ Others saw Reymond as helping Haeckel, who was rumoured to have kept a copy in his jacket pocket (May 1909, p. 116), even though many verses cut nearer the bone than those about amphioxus. In Jena "some of the best bits ... were read out before the ... zoology practical". ${ }^{12}$

English-speakers familiar with Haeckel's books, and the debates over them, enjoyed Reymond's verses too. In 1878 the British-born, Göttingen-educated Toronto palaeontologist and poet Edward John Chapman translated the first amphioxus song. His biologist colleague Robert Ramsay Wright had paid this animal much attention when reviewing the Anthropogenie for the local scientific society, the Canadian Institute. Like most professors, he found the book "admirably lucid" while regretting the "assertive tone", "dogmatism" and "cavalier treatment" of opponents (Wright 1876). Under the pseudonym Dr. Agorastes ("marketeer"), perhaps taken from Lucian's Sale of philosophies, Chapman dedicated his translation to Wright and the institute. ${ }^{13}$ But Amphioxus and ascidian, our gelatinous ancestors "imitated" as much as it translated; compare what follows with my more literal rendition above. Chapman added information, colour and drama, accommodated with an extra line in each of three fewer verses, as he turned a drinking song into a lyric poem, a pictureless "piece of jocose rhyming" in the style of Samuel Taylor Coleridge, to be declaimed more than sung. ${ }^{14}$

\footnotetext{
11 "Der moderne Prometheus", Periodische Blätter zur wissenschaftlichen Besprechung der großen religiösen Fragen der Gegenwart, 6 (Juli 1878), 92-100; M[üller] (1877).

12 W. Breitenbach quoted in a flyer for Reymond (1912).

13 Agorastes (1878). Wolfe (1966) does not list this first edition, but Chapman (1899, pp. 81-88) includes the verses.

${ }^{14}$ Not included here are the marginal titles Chapman gave each verse, e.g., "Horrid advent of an anatomist", or the one historical note. Though the subtitle referred to "missing links", there is little of the anxiety sometimes associated with that term: Beer (1996, pp. 115-145). Chapman does not seem to have translated Straubinger's song, which offered less lyrical potential.
} 
A slimy lancelet once lay

Half-hidden in the golden sand

Of Naples' blue and balmy bay-

And thought-how pleasant, here, to-day

Is Posilippo's strand.

But on the horizon's shadowy brim

A horrid vision doth arise-

A spectacled Professor grim!

All things that creep, crawl, fly, or swim,

Must he anatomize!

A "find" his eager senses sniff-

He stoops-he sees: with joy elate

He grasps the creature in a jiff-

And cries—now, I'll be jiggered-if

It isn't vertebrate!

The victim groan'd- "Come, that's too pale-

Don't try on me that precious cram-

Limpid and soft from top to tail,

I'm nothing but a naked snail-

Ask Pallas what I am!"

The horrid "Zoo" made answer, "nay!

I mean, my dear, myself to 'fix' it:

No wise man trusts what others say,

Or heeds, in this far-searching day,

The dead Past's ipse dixit!"

So saying, without more ado,

(To tender feeling sadly callous)

He slit poor Slimy through and through,

And bottled-as he'd bottle you-

This pseudo-snail of Pallas!

And thus, although the little nata-

Torial beast has no backbone,

For reasons based on larval data

It came among the Vertebrata

A place, at last, to own!

Pass thirty years and two-Ah me!

How quick Time gallops!-Then there came

A learned Russ to that blue sea-

To fish for tunicates came he,

Also to fish for fame! 
And so before his zeal should flag,

Or fall below its high meridian ${ }^{15}$

To work he went with dredge and drag,

And fished up quite a thumping bag

Of things ascidian!

And then came out the startling truth-

Let all the world's four corners hear it!

The ascidian in its frisky youth

Is half a vertebrate, in sooth,

Or something somewhere near it!

Swift sped the news o'er land and sea,

Till reaching Haeckel's ears-that great

Stem-framer-in vacation free-

Pack'd up, and went post-haste to see

This yea-nay vertebrate!

And there, our great Ontogenist-

Whose word bewitches whilst it shocks us-

Beheld the links his System miss'd:

Yes, here they were-or he'd be hiss'd-

Ascidian-Amphioxus!

All things are sure to one who waits:

And here the links at last were seen

Made manifest to meanest pates-

Invertebrated Vertebrates-

Fishes and worms between!

Thus, haeckelism's wondrous gleam

Makes clear, to all, how all arose-

Backward and forward went the stream

Of shifting forms, like shapes of dream,

And found in us its close!

Chapman thus replaced the toast with a Romantic scene that perhaps foresaw endless revision to the pedigree.

\section{Hats off to amphioxus}

Meanwhile, the German controversy over Haeckel raged on. In the Neue Freie Presse (New free press) of Vienna Vogt analysed Haeckel's metamorphosis from "apostle" through "prophet" to "oracle". Vogt ironically confessed as his own "gravest sin" that he had denied human kinship with ascidians and amphioxus and lampooned Haeckel's “enthusiastic exaggeration”. He now protested against even

\footnotetext{
${ }^{15}$ I have touched the highest point-/And from that full meridian of my glory/I haste now to my setting.-Shakespeare. [Chapman's note.]
} 


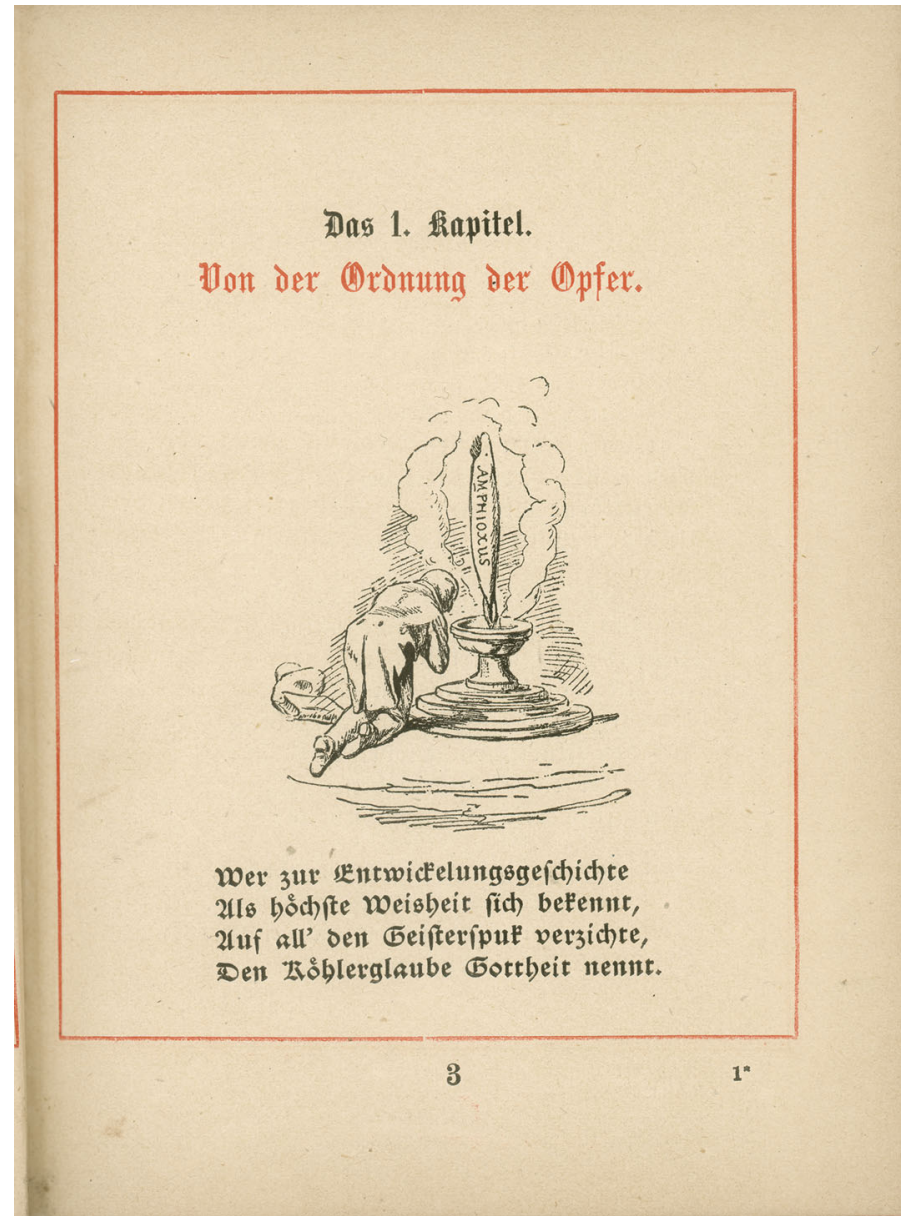

Fig. 5 The cult of amphioxus in Moritz Reymond's Leviticus: the high priest Haeckel kneels as he gives instructions on bringing offerings. By Fritz Steub, from Reymond (1880a, p. 3). Border $10.5 \times 8.2 \mathrm{~cm}$

more extreme "hyperbolicization" by exclaiming with reference to the demand of the Austrian tyrant defied by the Swiss patriot Wilhelm Tell: "How long will it be before we have an edict that we must doff our hats to a jar of amphioxus, like in front of Geßler's pole with a hat on top!" (Vogt 1877). In Reymond's verses, which developed this criticism, not long.

Following the second book of the breviary, the more critical Exodus, a new instalment containing books three to five, Leviticus, Numbers and Deuteronomy, completed the Pentateuch in 1880. These still poked fun at the pedigrees, and now also satirized the latest debates by imagining the establishment of Haeckelism as the state religion and Haeckel's installation as high priest of an amphioxus cult. Leviticus, or "the law for the prophets of the gospel of development", opened with Steub's sketch of a kneeling Haeckel (Fig. 5) and this verse (Reymond 1880a, pp. 3-4): 
Wer staunte nicht das edle Wesen

Voll Ehrfurcht und Verwund'rung an, Durch das die Wissenschaft genesen Vom alten blinden Schöpfungswahn?

Das unsers Menschenstammbaums Lücke Mit seiner Herrlichkeit erfüllt, Als goldene Erkenntnisbrücke Uns den Entwicklungsplan enthüllt?!
Who wouldn't marvel with reverence, Full of admiration most bold For the noble one which freed science From blind creationism old?

That golden bridge of discovery Which with glory magnificent Fills a great gap in man's pedigree, And reveals our development?!

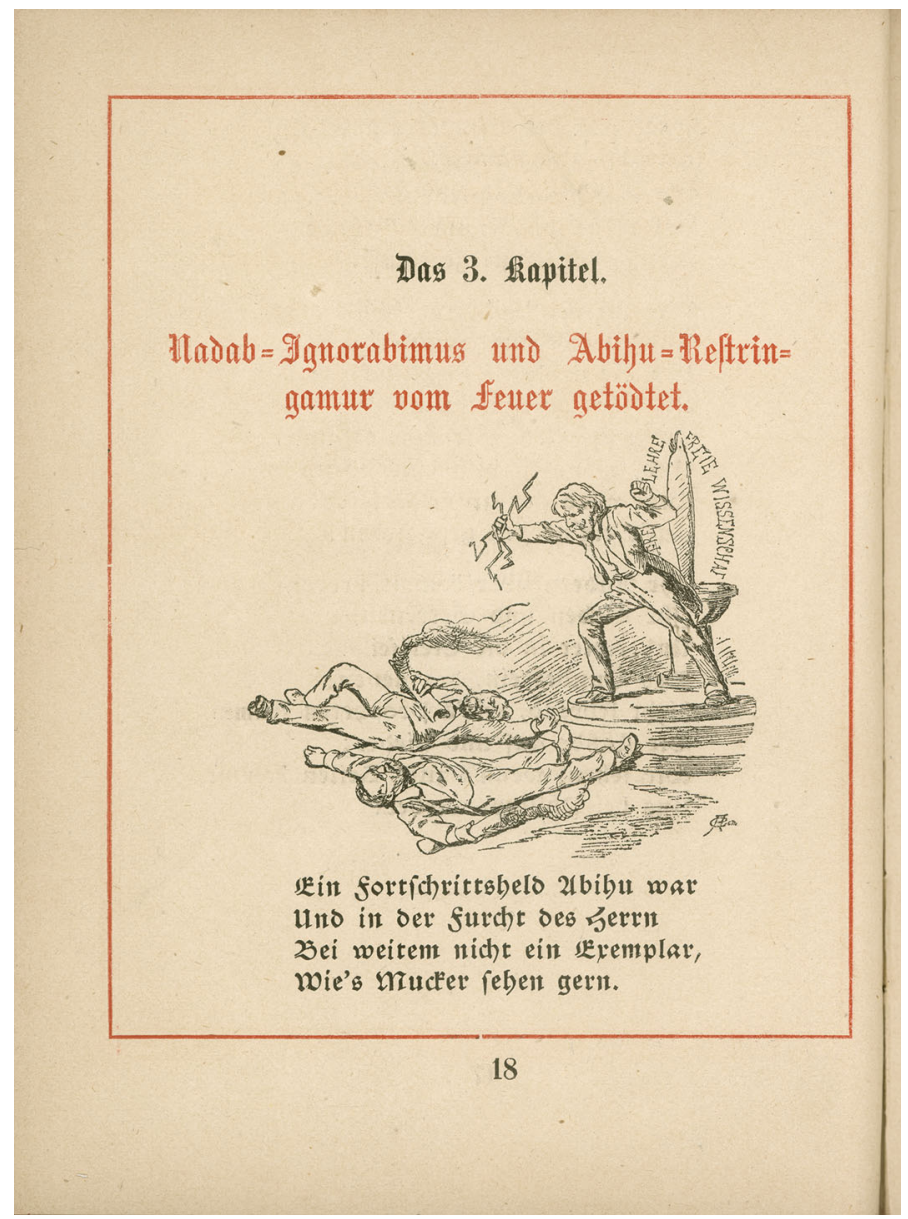

Fig. 6 "Nadab-Ignorabimus and Abihu-Restringamur killed by fire". Du Bois-Reymond had declared "Ignorabimus" (We shall not know): scientists would never solve certain riddles. Virchow had urged caution-"Restringamur" (Let us exercise restraint), as Haeckel put it-in order not to turn people against science. By Fritz Steub, from Reymond (1880a, p. 18) 
The singer argued that if psalms must be sung, then to this little fish; if offerings made, then to the first animal ever to develop vertebrae, a "headless-unconscious great deed of development" by the "ancestor and creator" of human beings. There should be no blood sacrifice, however. Haeckel was presented as tempted to do away with some senior professors-he disliked "Berlin biology" — but as choosing to give up dubious doctrines instead. In real life he maintained to the end, for example, the place of ascidians in the human stem-tree.

If, when ordaining the Darwinist priests, Reymond's Haeckel detected any concession to creationism and teleology or scepticism towards recapitulation, he felled them with a lightning bolt and finished them off with "bad jokes" (Reymond 1880a, pp. 10-17). His pamphlet on freedom in science and learning slaughtered the traitors Abihu, that is the left-liberal pathologist Rudolf Virchow, who had opposed the teaching of evolution in the schools, and Nadab, alias Reymond (1880a, pp. 18-25) (Fig. 6). Peace came when, like Yahweh quashing the rebellion of the tribes of Israel by causing Aaron's rod to bud, Darwin ended his followers' rivalry by keeping evergreen only Haeckel's tree of "gastrae', amphiox and ape". ${ }^{16}$ Reymond parodied Haeckel's cult, but reflected the consensus on the ancestral status of amphioxus.

\section{This exquisite form}

Having subsided in the 1880s, Darwinist debate revived in the following decade. From 1899 Haeckel's bestselling anticlerical synthesis Die Welträthsel, translated as The Riddle of the Universe, expanded the audience for science, took him to dizzying heights of international notoriety and fame, and created a market for a fresh English translation of The Evolution of Man (Hopwood 2015, p. 167). New readers also discovered the Laienbrevier, including in the US (Kellogg 1908). According to an "anniversary edition", Haeckel recommended it to students too busy drinking and fencing for lectures (Reymond 1912, p. 251). He still praised amphioxus as "after man the most important and interesting of all vertebrate animals", a claim his translator exaggerated by omitting the "vertebrate" (Haeckel 1903, II, p. 441; Haeckel 1905, II, p. 419; see also Haeckel 1874, p. 298; Haeckel 1899, p. 69). Even as speculation about ancestors was going out of fashion, many biologists agreed on the merits of "[t]his exquisite form" (H. F. Osborn in Willey 1894, p. ix).

Encyclopaedias acknowledged that some scientists put the "stem-father of all vertebrates" in a degenerate line (Meyers Großes Konversations-Lexikon 1905, pp. 454-455). Yet as research on amphioxus produced a huge volume of articles, books and models (e.g., Hatschek 1881; Willey 1894; Hopwood 2002, pp. 34-35, 101, 146), it thrived as (a relative of) an ancestor and for other reasons too. Accessible on various coasts, if hard to culture, it featured prominently in surveys (Balfour 1881, pp. 1-7; Korschelt and Heider 1892, II, pp. 1429-1467). Because "all the fundamental structures of the body are laid down with schematic clearness", it provided an "unrivalled" introduction to embryology and "a refuge to the perplexed embryologist" (Willey 1894, p. 104).

\footnotetext{
16 Reymond (1880a, pp. 80-86). The reference was to praise for the Schöpfungsgeschichte in Darwin (1871, I, p. 4), too early really to have played this role.
} 
The "Amphioxus song", produced in and for biological summer schools in the interwar US, rejoices in this classroom staple:

A fish-like thing appeared among the annelids one day;

It hadn't any parapods or setae to display.

It hadn't any eyes or jaws or ventral nervous cord,

But it had a lot of gill slits and it had a notochord.

Chorus:

It's a long way from Amphioxus,

It's a long way to us.

It was a long way from the German tradition and Reymond's Haeckelism to these more technical, less historical verses. But laughter over Haeckel's cult still echoes in biologists' amused pride in an animal which, for all his efforts, never quite became a household deity or even a household word. ${ }^{17}$

This look at the public life of amphioxus in its early years of fame has sought, on the one hand, to do more justice to its dominance than accounts that have dwelled on controversy over the ascidian theory and then the diverse challenges to what long remained the dominant view. It has contributed, on the other, to appreciation of the aesthetic dimensions of Darwinism and of species choice. Running through some of the fiercest battles in the history of science are smiles at Haeckel's excesses easing acceptance that he spoke a core of truth, ancestor-worship that self-consciously imitated a religious cult, and affection for Naples as the site of discoveries that revealed ancient history along the Mediterranean shore.

Acknowledgments I thank Ariane Dröscher, Silvia De Renzi and Staffan Müller-Wille for comments on drafts, Elizabeth Smith and Ivo Asmus (Universitätsbibliothek Greifswald) for advice, the ErnstHaeckel-Haus for access to manuscripts, Ian Bolton for scanning and the Wellcome Trust [088708] for support.

Open Access This article is distributed under the terms of the Creative Commons Attribution License which permits any use, distribution, and reproduction in any medium, provided the original author(s) and the source are credited.

\section{References}

Agorastes [pseudonym of Chapman, E. J.]. (1878). Amphioxus and ascidian, our gelatinous ancestors: How the missing links were discovered and made known. Toronto. archive.org/details/cihm_00778.

Balfour, F. M. (1881). A treatise on comparative embryology, Vol. 2. London: Macmillan.

Bayertz, K., Gerhard, M., \& Jaeschke, W. (Eds.). (2007). Weltanschauung, Philosophie und Naturwissenschaft im 19. Jahrhundert, Bd. 3: Der Ignorabimus-Streit. Hamburg: Meiner.

Beer, G. (1996). Open fields: Science in cultural encounter. Oxford: Oxford University Press.

Beeson, R. J. (1978). Bridging the gap: The problem of vertebrate ancestry, 1859-1875. PhD thesis, Oregon State University.

Belgum, K. (1998). Popularizing the nation: Audience, representation, and the production of identity in Die Gartenlaube, 1853-1900. Lincoln: University of Nebraska Press.

\footnotetext{
17 More specialized poems communicated the research of the British zoologist Walter Garstang on the evolution of larval forms and criticized Haeckel's doctrine of recapitulation: Garstang (1951).
} 
Bertrand, S., \& Escriva, H. (2011). Evolutionary crossroads in developmental biology: Amphioxus. Development, 138, 4819-4830.

Blackbourn, D. (1997). The Fontana history of Germany, 1780-1918: The long nineteenth century. London: Fontana.

Bock, C. E. (1875). Zur Abstammungslehre. Der Thiere Ahnenreihe. Gartenlaube, 23, 7-9.

Bowler, P. J. (1996). Life's splendid drama: Evolutionary biology and the reconstruction of life's ancestry, 1860-1940. Chicago: University of Chicago Press.

Brantlinger, P. (2003). Dark vanishings: Discourse on the extinction of primitive races, 1800-1930. Ithaca, NY: Cornell University Press.

Browne, J. (2001). Darwin in caricature: A study in the popularisation and dissemination of evolution. Proceedings of the American Philosophical Society, 145, 496-509.

Caianiello, S. (2014). Succession of functions: From Darwin to Dohrn. History and Philosophy of the Life Sciences (this issue).

Chapman, E. J. (1899). A drama of two lives, the snake-witch, a Canadian summer-night and other poems. London: Kegan Paul, Trench, Trübner.

Darwin, C. (1871). The descent of man, and selection in relation to sex, 2 vols. London: Murray.

Daum, A. W. (1998). Wissenschaftspopularisierung im 19. Jahrhundert. Bürgerliche Kultur, naturwissenschaftliche Bildung und die deutsche Öffentlichkeit, 1848-1914. München: Oldenbourg.

De Ceglie, R. (1999). “L'anello mancante”. L’opera di O. G. Costa nella biologia italiana del primo Ottocento. Bari: Laterza.

Dohrn, A. (1875). Der Ursprung der Wirbelthiere und das Princip des Functionswechsels. Genealogische Skizzen. Leipzig: Engelmann.

Fokin, S. I. (2012). Life of Alexander Onufrievich Kowalevsky (1840-1901). Evolution and Development, 14, 3-8.

Fokin, S. I., \& Groeben, C. (Eds.). (2008). Russian scientists at the Naples Zoological Station, 1874-1934. Napoli: Giannini.

Fortey, R. (2011). Survivors: The animals and plants that time has left behind. London: Harper.

Garstang, W. (1951). Larval forms and other zoological verses, with an introduction by A. C. Hardy. Oxford: Blackwell.

Gee, H. (1996). Before the backbone: Views on the origin of the vertebrates. London: Chapman and Hall.

Gee, H. (2008). The amphioxus unleashed. Nature, 453, 999-1000.

Gegenbaur, C. (1859). Grundzüge der vergleichenden Anatomie. Leipzig: Engelmann.

Ghiselin, M. T. (1994). The origin of vertebrates and the principle of succession of functions: Genealogical sketches by Anton Dohrn, 1875. An English translation from the German, introduction and bibliography. History and Philosophy of the Life Sciences, 16, 3-96.

Groeben, C. (1995). Der Freskensaal der Stazione Zoologica Anton Dohrn. Biographie eines Kunstwerkes. Napoli: Macchiaroli.

Groeben, C., \& Gambi, M. C. (Eds.). (1992). Lo Guarracino che jeva pe mare. Napoli: Macchiaroli.

Haeckel, E. (1866). Generelle Morphologie der Organismen. Allgemeine Grundzüge der organischen Formen-Wissenschaft, mechanisch begründet durch die von Charles Darwin reformirte Descendenz-Theorie, 2 Bde. Berlin: Reimer.

Haeckel, E. (1868a). Natürliche Schöpfungsgeschichte. Gemeinverständliche wissenschaftliche Vorträge über die Entwickelungslehre .... Berlin: Reimer.

Haeckel, E. (1868b). Ueber die Entstehung und den Stammbaum des Menschengeschlechts. Zwei Vorträge. Berlin: Lüderitz.

Haeckel, E. (1870). Natürliche Schöpfungsgeschichte ..., 2. Aufl. Berlin: Reimer.

Haeckel, E. (1874). Anthropogenie oder Entwickelungsgeschichte des Menschen. Gemeinverständliche wissenschaftliche Vorträge über die Grundzüge der menschlichen Keimes- und StammesGeschichte. Leipzig: Engelmann.

Haeckel, E. (1875). Ziele und Wege der heutigen Entwickelungsgeschichte. Jena: Dufft.

Haeckel, E. (1899). Die Welträthsel. Gemeinverständliche Studien über Monistische Philosophie. Bonn: Strauß.

Haeckel, E. (1903). Anthropogenie oder Entwickelungsgeschichte des Menschen. Keimes- und StammesGeschichte, 5. Aufl., 2 Bde. Leipzig: Engelmann.

Haeckel, E. (1905). The evolution of man: A popular scientific study (J. McCabe, Trans.), 2 vols. London: Watts.

Hatschek, B. (1881). Studien über Entwicklung des Amphioxus. Arbeiten aus dem Zoologischen Institute der Universität Wien und der Zoologischen Station in Triest, 4, 1-88, Taf. I-IX. 
Hopwood, N. (2002). Embryos in wax: Models from the Ziegler studio, with a reprint of "Embryological wax models" by Friedrich Ziegler. Cambridge: Whipple Museum of the History of Science; Bern: Institute of the History of Medicine.

Hopwood, N. (2011). Approaches and species in the history of vertebrate embryology. In F. J. Pelegri (Ed.), Vertebrate embryogenesis: Embryological, cellular and genetic methods. Methods in molecular biology (Vol. 770, pp. 1-20). New York: Humana Press.

Hopwood, N. (2015). Haeckel's embryos: Images, evolution and fraud. Chicago: University of Chicago Press.

Huber, J. (1874). Wissenschaftliche Tagesfragen. I. Darwins Wandlungen und Häckels "natürliche Schöpfungsgeschichte" (Schluß). Allgemeine Zeitung, Nr. 162B (11. Juni), 2515-2516.

Jackson, M. W. (2003). Harmonious investigators of nature: Music and the persona of the German Naturforscher in the nineteenth century. Science in Context, 16, 121-145.

Jefferies, M. (2003). Imperial culture in Germany, 1871-1918. Basingstoke: Palgrave Macmillan.

Kellogg, V. L. (1908). Evolution in rhyme. Science, 27 (15 May), 791-792.

Kelly, A. (1981). The descent of Darwin: The popularization of Darwinism in Germany, 1860-1914. Chapel Hill: University of North Carolina Press.

Korschelt, E., \& Heider, K. (1892). Lehrbuch der vergleichenden Entwicklungsgeschichte der wirbellosen Thiere, Specieller Theil, Zweites Heft. Jena: Fischer.

Kühn, A. (1950). Anton Dohrn und die Zoologie seiner Zeit. Napoli: Stazione Zoologica.

Maienschein, J. (1994). "It's a long way from amphioxus": Anton Dohrn and late nineteenth-century debates about vertebrate origins. History and Philosophy of the Life Sciences, 16, 465-478.

May, W. (1909). Ernst Haeckel. Versuch einer Chronik seines Lebens und Wirkens. Leipzig: Barth.

Meyers Großes Konversations-Lexikon. Ein Nachschlagewerk des allgemeinen Wissens. (1905). 6. Aufl., Bd. 1. Leipzig: Bibliographisches Institut.

Mikhailov, A. T., \& Gilbert, S. F. (2002). From development to evolution: The re-establishment of the “Alexander Kowalevsky Medal”. International Journal of Developmental Biology, 46, 693-698.

M[üller], K. (1877). Stylistische Mittheilungen. Der Humor in der Naturwissenschaft. Die Natur, n.s., 3, $80-81$.

Neyer, H. J. (2009). Zoologia comica. Charles Darwin und Wilhelm Busch. Satire. Mitteilungen der Wilhelm-Busch-Gesellschaft, 71, 8-26.

Nyhart, L. K. (1995). Biology takes form: Animal morphology and the German universities, 1800-1900. Chicago: University of Chicago Press.

Putnam, N. H., et al. (2008). The amphioxus genome and the evolution of the chordate karyotype. Nature, $453,1064-1071$.

Reymond, M. (1877). Das neue Laienbrevier des Haeckelismus. Genesis oder die Entwickelung des Menschengeschlechts. Nach Häckel's Anthropogenie in zierliche Reimlein gebracht. Bern: Frobeen.

Reymond, M. (1878). Das neue Laienbrevier des Häckelismus, Teil 1: Genesis oder die Entwickelung des Menschengeschlechts. Nach Häckel's Anthropogenie in zierliche Reimlein gebracht, 3. Aufl. Bern: Frobeen.

Reymond, M. (1880a). Das neue Laienbrevier des Häckelismus, Teil 3: Leviticus-Numeri-Deuteronomium oder das Entwickelungs-Evangelium und seine Propheten. Bern: Frobeen.

Reymond, M. (1880b). Wo steckt der Mauschel? oder Jüdischer Liberalismus und wissenschaftlicher Pessimismus. Ein offener Brief an W. Marr, 4. Aufl. Bern: Frobeen.

Reymond, M. (1912). Laienbrevier des Haeckelismus. Jubiläumsausgabe 1862-1882-1912. München: Reinhardt.

Richards, R. J. (2008). The tragic sense of life: Ernst Haeckel and the struggle over evolutionary thought. Chicago: University of Chicago Press.

Semper, C. (1875). Die Stammesverwandtschaft der Wirbelthiere und Wirbellosen. Arbeiten aus dem zoologisch-zootomischen Institut in Würzburg, 2, 25-76.

Semper, C. (1876a). Die Verwandtschaftsbeziehungen der gegliederten Thiere. III. Strobilation und Segmentation. Ein Versuch zur Feststellung specieller Homologien zwischen Vertebraten, Anneliden und Arthropoden. Arbeiten aus dem zoologisch-zootomischen Institut in Würzburg, 3, 115-404.

Semper, C. (1876b). Der Haeckelismus in der Zoologie. Ein Vortrag gehalten am 28. October $1875 \mathrm{im}$ Verein für Kunst und Wissenschaft zu Hamburg, unter dem Titel "Der neue Glaube und die moderne Zoologie”. Hamburg: Mauke's Söhne.

Semper, C. (1877). Offener Brief an Herrn Prof. Haeckel in Jena. Hamburg: Mauke Söhne. 
Smocovitis, V. B. (2009). Singing his praises: Darwin and his theory in song and musical production. Isis, $100,590-614$.

Stafford, F. J. (1994). The last of the race: The growth of a myth from Milton to Darwin. Oxford: Clarendon.

Sterne, C. (1875). Menschliche Erbschaften aus dem Thierreiche. Gartenlaube, 23, 266-268.

Vogt, C. (1875). Wissenschaftliche und unwissenschaftliche Bücherei. II. Des Darwinisten Zweifel. Frankfurter Zeitung, Nr. 43 (12. Feb., Morgenblatt), 1-2.

Vogt, C. (1877). Apostel-, Propheten- und Orakelthum in der Wissenschaft. IV. Frankfurter Zeitung, Nr. 95 (5. Apr.), 1-3.

Willey, A. (1894). Amphioxus and the ancestry of the vertebrates. New York: Macmillan.

Wolfe, R. (1966). Edward John Chapman, 1821-1904: An essay in bibliography, typescript. Toronto.

Wright, R. R. (1876). Haeckel's “Anthropogenie”. Canadian Journal of Science, Literature and History, 15, 231-248.

Zacharias, O. (1875a). Ernst Häckel's “Anthropogenie”. Illustrirte Zeitung, 64, Nr. 1646 (16. Jan.), 42; Nr. 1647 (23. Jan.), 68-69; Nr. 1650 (13. Feb.), 119; Nr. 1651 (20. Feb.), 140-142.

Zacharias, O. (1875b). Häckels Anthropogenie. Ausland, 48, 210-213. 